\title{
Clinical and Biochemical Predictors of Fatality in Traumatic Brain Injury
}

\author{
Kadhaya David Muballe ${ }^{1, *}$, Sewani Constance Rusike ${ }^{2}$, Benjamin Longo-Mbenza ${ }^{3}$, Jehu Iputo ${ }^{2}$ \\ ${ }^{1}$ Department of Neurosurgery, Walter Sisulu University, Mthatha, South Africa \\ ${ }^{2}$ Department of Physiology, Walter Sisulu University, Mthatha, South Africa \\ ${ }^{3}$ Department of Public Health, Walter Sisulu University, Mthatha, South Africa
}

Email address:

kmuballe@yahoo.co.k (K. D. Muballe)

${ }^{*}$ Corresponding author

\section{To cite this article:}

Kadhaya David Muballe, Sewani Constance Rusike, Benjamin Longo-Mbenza, Jehu Iputo. Clinical and Biochemical Predictors of Fatality in Traumatic Brain Injury. Journal of Surgery. Vol. 8, No. 5, 2020, pp. 140-152. doi: 10.11648/j.js.20200805.11

Received: June 24, 2020; Accepted: July 20, 2020; Published: August 13, 2020

\begin{abstract}
Traumatic brain injury is a global health problem, it is a major cause of devastating neurological sequelae and significant mortality. The underlying physiological events in traumatic brain injury are responsible for the poor clinical outcomes seen in patients. Inflammatory and oxidative stress changes in traumatic brain injury result in the release of inflammatory biomarkers, a reduction in the endogenous anti-oxidants and dysfunction of the blood brain barrier. An understanding of the natural history of oxidative stress and inflammatory changes in traumatic brain injury can help design appropriate management protocols to reduce mortality and morbidity in these patients. Aim of the study: The aim of this study was to identify potential biomarkers that are predictive of fatality in patients with moderate to severe traumatic brain injury. Methods: This was a prospective study of patients with moderate to severe traumatic brain injury managed at the Nelson Mandela Academic Hospital during the period March 2014 - March 2016. Following admission and management, the patient demographics (sex, age) and admission Glasgow Coma Score were recorded. Oxidative stress and inflammatory biomarkers in blood and cerebrospinal fluid where sampled on day 1 to 7 . On day 14 only blood was sampled for the same biomarkers. The primary outcome was the Glasgow Outcome score assessed on day 90. Due to its simplicity the Glasgow Outcome scale was used to assess clinical outcomes at day 90 . Because of difficulty in regular follow up due to the vastness of our region, difficult terrain and long travel distances a 3 month follow up period was used to avoid default. Results: Of the 64-patient's, fatality was noted in $12.5 \%$ of them. There was a significant association between fatality and the; ages of the patients, anti-oxidant levels, proinflammatory biomarkers and admission Glasgow Coma Score. Conclusion: The admission Glasgow Coma Score, low antioxidant levels and elevated serum interleukin- $1 \beta$ levels were associated with fatal outcomes.
\end{abstract}

Keywords: Traumatic Brain Injury, Age, Anti-oxidants, Glasgow Outcome Score, Interleukins, Fatality

\section{Introduction}

Traumatic brain injury (TBI) is a significant cause of morbidity and mortality worldwide $[4,49]$. Severe TBI is often associated with unfavourable outcomes with increased mortality among these patients $[3,5]$.

In traumatic brain injury, prognostic information is important not only in the counselling of the relatives but also to aid in providing effective therapeutic strategies. An earlier study noted that prognostication using computer based models can lead to effective use of resources in TBI patients
[56]. Outcomes in traumatic brain injury (TBI) are dependent on several factors including, intracranial pressure (ICP), cerebral perfusion, metabolic function and oxygenation. Measurements of ICP, cerebral blood flow and cerebral perfusion pressure are necessary in order to avoid hypoperfusion, hyper-perfusion or hypoxia as these factors affect the state of cerebral oxygen consumption [34, 47, 81]. Traumatic brain injury is associated with, an increased generation of superoxide anions and hydroxyl radicals, this sets in motion a vicious cycle of oxidative damage which can lead to poor clinical outcomes in the patients $[7,29,88]$. These reactive oxygen intermediates including superoxide 
anions, hydroxyl radicals, hydrogen peroxide and hypochlorous acid cause oxidative damage to cellular proteins and nucleic acids in addition to lipid peroxidation [37]. In traumatic brain injury there is accelerated lipid peroxidation with resultant increase in generation of malondialdehyde (MDA) and 4-hydroxynonenal (4-HNE) or 2-propenol (acrolein), which cause brain edema and neuronal damage [75, 82].

The accelerated lipid peroxidation leading to increased generation of neurotoxic products in TBI disrupts the blood brain barrier, worsening cerebral oedema and intracranial pressure and often results in poor outcomes [75]. Termination of lipid peroxidation occurs in reactions involving lipid radicals with endogenous anti-oxidants.

An increased expression of inflammatory mediators such as cytokines occurs in the cerebrospinal fluid and blood of traumatic brain injury patients [26, 40, 45, 85]. The secondary brain injury process integrates the chemokines, cytokines, complement factors and the oxidative stress factors $[6,12,70]$.

Delayed or inadequate management of TBI may propagate an unregulated acute inflammatory response and may put in motion a vicious cycle of inflammatory damage $[15,29,31$, $36,50,57,66,68,76,79,88]$.

Major inflammatory cytokines including Interleukin-1 $\beta$ (IL-1 $\beta), \quad$ interleukin-4 (IL-4), interleukin-6 (IL-6), interleukin-10, tumor necrosis factor alpha (TNF- $\alpha$ ) and interleukin-18 are involved in traumatic brain injury. Tumor necrosis factor- $\alpha$ (TNF- $\alpha$ ), interleukin- $\beta$ and interleukin18 are pro-inflammatory cytokines. The anti-inflammatory mediators limit and control the effects of the proinflammatory cytokine response [55]. Basic Inflammatory mediators including TNF- $\alpha$, IL- $1 \beta$ and IL- 6 elevated soon after traumatic brain injury, may exacerbate the inflammatory process causing neuronal tissue damage and may worsen the brain edema [2, 24, 65]. Though Glasgow Coma Score (GCS) is important in assessing the state of consciousness [74], it has great limitations and may be inconsistent when assessing survival and functional outcomes among TBI patients $[13,21]$. Current management strategies in TBI have focussed on factors such as; the admission Glasgow Coma Score, puppilary reactivity, age of the patient, mechanism of injury [30], computerized tomography (CT) scan findings [48], intracranial pressure (ICP) and brain tissue oxygen tension $\left(\mathrm{PBO}_{2}\right)$, little or no information regarding the impact of oxidative stress imbalance and inflammatory changes in TBI on outcomes can be deduced from this parameters.

It is necessary to look for comprehensive clinical and biomarker profiles that would guide treatment of patients with moderate to severe traumatic brain injury.

\subsection{Inclusion Criteria}

1. Patients with moderate to severe Traumatic brain injury $(\mathrm{GCS} \leq 12)$ admitted to the neurosurgical service at the Nelson Mandela Academic Hospital in whom neuromonitoring and surgical intervention were indicated.
2. Patients with intracranial pathology requiring neurosurgical intervention and or temporary cerebrospinal fluid diversion to reduce intracranial pressure.

3. Patients and relatives who gave clear informed consent to participate in the study.

\subsection{Exclusion Criteria}

1. Patients whose relatives refused to participate in the study. 2. Patients in whom neuromonitoring was not carried out due to logistical problems.

3. Patients not admitted to the neurosurgical service.

4. Patients who died while still in the accident and emergency department before admission or initiation of standard and routine medical and surgical management.

\section{Methods}

This study on patients with moderate to severe TBI admitted to the Nelson Mandela Academic Hospital from March 2014 to March 2016. The patients admitted underwent craniotomy and or craniectomy and had Intra-cranial pressure and brain tissue oxygen tension monitoring performed.

Post operatively the patients were admitted to the intensive care unit (ICU) were ventilation, sedation, analgesia and monitoring of the ICP, $\mathrm{PBO}_{2}$ and brain tissue temperatures was done.

Daily blood and cerebrospinal (CSF) fluid samples were taken for evaluation of inflammatory and oxidative stress biomarkers from day 1 - day 7 . On day 14 blood was sampled for evaluation of these biomarkers. Serum and cerebrospinal fluid total anti-oxidant capacity and superoxide dismutase (SOD) activities were analysed. The serum malondialdehyde (MDA) levels were assessed using thiobarbituric acid reactive substances (TBARS) assay while the inflammatory biomarkers in serum including; IL-1 $\beta$, IL-6 and IL-10 were assayed using the Biolegend Elisa method. The patients were reviewed at 2 weeks and 12 weeks during which time the Glasgow Outcome Score assessment was done.

\subsection{Sample Collection and Storage}

The blood samples were collected by venipuncture into sterile vacutainers (Becton Dickinson or BD) non EDTA containing tubes. Following centrifugation of blood samples for 13 minutes at 3000 revolutions per minute, the supernatant (serum) was pipetted into vacutainer tubes. Aliquots were then placed into cryovials bearing the patients name, date and time of collection before storage at $-80^{\circ} \mathrm{C}$. Cerebrospinal fluid samples were also pippeted into cryovials and stored at $-80^{\circ} \mathrm{C}$.

\subsection{Malondialdehyde Assay by Evaluation of Thiobarbituric Acid Reactive Substances (TBARS)}

The OxiSelect ${ }^{\mathrm{TM}}$ TBARS Assay Kit for malondialdehyde Quantitation by Cell Biolabs, Inc. 7758 Arjons Drive San Diego, CA 92126) was used.

Assay of Malondialdehyde (MDA) using thiobarbituric 
acid reactive substances (TBARS) method is used for monitoring lipid peroxidation. The procedure was performed as per manufacturer specifications.

\subsection{Superoxide Dismutase Assay}

The superoxide dismutase (SOD) assay kit by Cayman chemical -USA 1180 E. Ellsworth RD. Ann Arbor MI, USA used.

The Caymans superoxide dismutase assay kit utilizes tetrazolium salt for detection of superoxide radicals generated by xanthine oxidase and hypoxanthine. One unit of SOD is the amount of enzyme needed to exhibit $50 \%$ of dismutation of the superoxide radical. This assay measures all the 3 types of superoxide dismutase $(\mathrm{Cu} / \mathrm{Zn}, \mathrm{Mn}$ and FESOD).

\subsection{Total anti-oxidant Capacity Assay by Frap Method}

Principle of frap assay

This method of evaluating the total anti-oxidant power is used to assess the ferric reducing potential of the sample. During this procedure, inactivation of oxidants was done in a redox reaction using reductants as the electron donating antioxidants. Reduction of ferric tripyridyltriazone to a ferrous state occurs at a low $\mathrm{pH}$ to produce an intense blue colour which was measured by the change in absorbance at $593 \mathrm{~nm}$. The change in absorbance was directly related to the total reduction of the electron donating anti-oxidants in the reaction.

\subsection{Interleukin Assay}

(BioLegend, Inc. BioLegend is ISO 9001: 2008 and ISO 13485: 2003 Certified 9727 Pacific Heights Blvd, San Diego, CA 92121).

Interleukin- $1 \beta$, interleukin- 6 and interleukin-10 assay was performed using the BioLegend's ELISA MAX ${ }^{\mathrm{TM}}$ Deluxe Sets. The assay was carried out as per manufacturer specifications.

\subsection{Ethical Considerations}

Before initiation of the study, Ethical and institutional approval had to be obtained from the Walter Sisulu University and the department of Health (WSU Protocol number 019/2013) according to the ethical guidelines of the Helsinki declaration of 1975 (principles).

\subsection{Data and Statistical Analysis}

Data analysis was carried out using statistical package for social sciences (SPSS) ${ }^{\circledR}$ Version 23.0 for Windows (IBM SPSS Inc New York, NY USA). Univariate and multivariate logistic regression models including; Receiver operating curves (ROC), Cox regression, Kaplan Meier estimates, were used to identify the variables that were independently associated with survival and recovery.

\section{Results}

\subsection{Potential and Independent Predictors of Fatality in Patients with Moderate to Severe TBI}

Predictors of Fatality from Admission to Discharge

In this study 64 patients with moderate to severe TBI were managed. The primary outcome was the Glasgow Outcome Score assessment at 90 days after TBI. Out of the 64 patients $12.5 \%(n=8)$ died after the $2^{\text {nd }}$ week and before the $3^{\text {rd }}$ week, among the surviving patients, 42 had a GOS of $\geq 4$ while the remaining $15 \%$ of patients had a GOS $\leq 3$.

There was a significant association between fatality and; age of patients, serum IL- $1 \beta$, serum TAC, cerebrospinal fluid SOD, CSF TAC, admission GCS.

\subsection{Univariate Analysis and ROC Curves to Predict Fatality}

Receiver operating curves of sensitivity vs. 1-specificity for age, serum inflammatory or oxidant biomarkers (serum IL-1 $\beta$, serum IL-10, serum MDA (by TBARS assay), (Figure 1) and for anti-oxidants (serum SOD, serum TAC, CSF SOD, CSF TAC) (Figure 1) were used to discriminate fatal from non-fatal TBI cases. However, there was no significant correlation between serum IL-6, serum SOD, CSF SOD, CSF TAC and fatality $(\mathrm{P}>0.05)$.

In this study, increased fatality was seen in; young patients ( $<20$ years), those with increased inflammatory or prooxidant biomarkers and in patients with low levels of antioxidant biomarkers.

The ROC methods were used to discriminate fatal cases and survivors, as shown in (Table 1). Thus, the prognostic performance of serum IL-1 $\beta$, serum IL-10, serum MDA (by TBARS assay), age, serum SOD, serum TAC, CSF-SOD and CSF TAC was according to the pattern seen in the area under curve (AUC).

Table 1. Univariate correlates of fatality.

\begin{tabular}{|c|c|c|c|}
\hline Variable of interest & Death \% (n) & Survival \% (n) & P-value \\
\hline \multicolumn{4}{|l|}{ Age groups in yrs. } \\
\hline $1-19$ & $18.2(4)$ & $81.8(18)$ & \multirow{3}{*}{0.049} \\
\hline $20-39$ & $8.6(3)$ & $91.4(32)$ & \\
\hline $40-62$ & $14.3(1)$ & $85.6(6)$ & \\
\hline \multicolumn{4}{|l|}{ Serum IL-1 $\beta$} \\
\hline$\geq 45 \mathrm{pg} / \mathrm{mL}$ & $25(3)$ & $75(9)$ & \multirow{2}{*}{$<0.001$} \\
\hline$\leq 45 \mathrm{pg} / \mathrm{mL}$ & $9.6(5)$ & $90.4(47)$ & \\
\hline$\geq 1.4 \mu \mathrm{mol} / \mathrm{L}$ & $22.2(4)$ & $77.8(14)$ & \multirow{2}{*}{0.035} \\
\hline$\leq 1.4 \mu \mathrm{mol} / \mathrm{L}$ & $10.9(5)$ & $89.1(41)$ & \\
\hline
\end{tabular}




\begin{tabular}{llll}
\hline Variable of interest & Death \% (n) & Survival \% (n) & P-value \\
\hline CSF SOD & & & \\
$\geq 0.3 \mathrm{IU} / \mathrm{mL}$ & $16.7(4)$ & $83.3(20)$ & 0.045 \\
$\leq 0.3 \mathrm{IU} / \mathrm{mL}$ & $10(4)$ & $90(36)$ & \\
Serum IL-10 & & $79.2(19)$ & $<0.0001$ \\
$\geq 60 \mathrm{pg} / \mathrm{mL}$ & $20.8(5)$ & $95.1(38)$ & $<0.0001$ \\
$\leq 60 \mathrm{pg} / \mathrm{mL}$ & $5(2)$ & $64.3(9)$ & $<0.001$ \\
Admission GCS & & $94(47)$ & \\
$\leq 7$ & $35.7(5)$ & $78.3(18)$ & \\
$>7$ & $6(3)$ & $92.9(39)$ & \\
Serum TAC & $21.7(5)$ & & \\
$\geq 450 \mu \mathrm{mol} / \mathrm{L}$ & $7.1(3)$ & & \\
$\leq 450 \mu \mathrm{nol} / \mathrm{L}$ & &
\end{tabular}

Table 2. Cutoff values as predictors of fatal outcome in TBI.

\begin{tabular}{lllll}
\hline Variable & Optimal Cutoff & Relative risk & 95\% CI & P-Value \\
\hline Admission GCS & $\leq 7$ & 6 & $3.3-10.7$ & $1.03-1.3$ \\
AGE group & $\leq 20$ years & 1.2 & $1.2-1.5$ & $<0.0001$ \\
Serum-IL1 pg/ml & $\geq 35$ & 1.4 & $1.2-1.5$ & $<0.001$ \\
Serum TBARS $\mu \mathrm{mol} / \mathrm{L}$ & $\geq 1.4$ & 1.3 & $1.3-1.8$ & $<0.0001$ \\
Serum SOD IU/mL & $\leq 0.3$ & 1.5 & $1.2-1.6$ & $<0.0001$ \\
Serum TAC $\mu \mathrm{mol} / \mathrm{L}$ & $\leq 450$ & 1.4 & $1.4-2.0$ & $<0.0001$ \\
CSF SOD IU/ml & $\leq 0.3$ & 1.7 & $1.3-1.8$ & $<0.0001$ \\
CSF TAC $\mu \mathrm{mol} / \mathrm{L}$ & $\geq 300$ & 1.6 & $<0.0001$ \\
\hline
\end{tabular}

Receiver operating curve methods identified the optimal cut-off values for serum IL- $1 \beta$ to be $\geq 45 \mathrm{pg} / \mathrm{mL}$, (area under curve [AUC] 0.629; 95\% CI 0.537-0.721 SE 0.0047 P=0.008 sensitivity $70 \%$, specificity $51 \%$ ) (Figure 1 ).

Using ROC methods, the optimal cut-off for serum MDA (or TBARS) was $\geq 1.4 \mu \mathrm{mol} / \mathrm{L}$ with prognostic and diagnostic performance defined by area under curve (AUC) $0.649 ; 95 \%$ CI $0.561-0736$; $\mathrm{SE}=0.045 ; \mathrm{P}$ value $=0.002$; sensitivity $73 \%$; specificity $=51 \%$, according to ROC (Figure 1 ).

Using the ROC methods, the optimal cut-off for CSF SOD was $\leq 0.4 \mathrm{IU} / \mathrm{mL} \quad(\mathrm{AUC}=0.647 ; 95 \% \quad \mathrm{CI}=0.548-0746$; $\mathrm{SE}=0.051$, $\mathrm{P}$ value $=0.003$, sensitivity $70 \%$, specificity $=50 \%$ ) according to ROC (Figure 1).

For interleukin-10 ROC methods ROC methods obtained the following; optimal cut-off for serum IL $10 \geq 60 \mathrm{pg} / \mathrm{mL}$ (AUC $=0.639 ; 95 \% \quad \mathrm{CI}=0.560-0.719, \quad \mathrm{SE}=0.041, \quad \mathrm{P}<0.004$, sensitivity $=75 \%$, specificity $=68 \%$ ) (Figure 1$)$.

Receiver operating curves identified the optimal cut-off for serum $\mathrm{TAC} \leq 450 \mu \mathrm{mol} / \mathrm{mL}$, (AUC 0.724; CI=0.629-0.819 $\mathrm{SE}=0.048, \quad \mathrm{P}<0.0001, \quad$ sensitivity $=70 \%, \quad$ specificity $=60 \%$ ) (Figure 1).

The cut-off for Glasgow Coma Score defined the following; GCS $\leq 7 \quad$ (AUC=0.867; 95\% CI=0.827-0.907, $\mathrm{SE}=0.020, \quad \mathrm{P}$ value $<0.0001$, sensitivity $84 \%$, specificity $=70 \%$ ) according to ROC methods.
The mean value of serum IL- $1 \beta$ associated with fatality was $45 \geq \mathrm{pg} / \mathrm{mL}$, Serum TBARS $\geq 1.4 \mu \mathrm{mol} / \mathrm{L}, \quad$ CSF $\mathrm{SOD} \leq 0.4 \mathrm{IU} / \mathrm{mL}$, Serum IL $10 \geq 60 \mathrm{pg} / \mathrm{mL}$, admission $\mathrm{GCS} \leq$ 7 , age groups $=1-19$ years, serum $\mathrm{TAC} \leq 450 \mu \mathrm{mol} / \mathrm{mL}$, were identified as significant univariate predictors of fatality in the study population.

The relative risk for fatality was multiplied by; $x 6, x 1.2$, $\mathrm{x} 1.4, \mathrm{x}-1.3, \mathrm{x} 1.5, \mathrm{x} 1.4, \mathrm{x} 1.7, \mathrm{x} 1.6$ in cases of GCS $<7$, age $<20$ years, serum IL- $1 \beta \geq 35 \mathrm{pg} / \mathrm{mL}$, serum TBARS $\geq 1.4$ $\mu \mathrm{mol} / \mathrm{L}$, serum SOD $\leq 0.3 \mathrm{IU} / \mathrm{mL}$, serum TAC $\leq 450 \mu \mathrm{mol} / \mathrm{mL}$, $\mathrm{CSF} \mathrm{SOD} \leq 0.3 \mathrm{IU} / \mathrm{mL}$ respectively.

\subsection{Multivariate Cox Regression Analysis to Predict Fatality in TBI}

After adjusting for confounding factors such as age groups, cerebrospinal fluid SOD, and serum TAC using Cox regression analysis, serum IL- $1 \beta \geq 45 \mathrm{pg} / \mathrm{mL}$ serum MDA (TBARS) $\geq 1.4 \mu \mathrm{mol} / \mathrm{L}$, serum IL $10 \geq 60 \mathrm{pg} / \mathrm{ml}$ and GCS at admission $\leq 7$ were identified as the most significant predictors for fatality (Table 3 ) thus the multivariate hazard ratio for mortality was multiplied by $\times 5, \times 4, \times 2, \times 2$, by admission GCS $<7$, serum IL $10 \geq 60 \mathrm{pg} / \mathrm{mL}$, serum MDA (TBARS) $\geq 1.4 \mu \mathrm{mol} / \mathrm{L}$, serum $\mathrm{IL}-1 \geq 45 \mathrm{pg} / \mathrm{mL}$ respectively (Table 1).

Table 3. Independent predictors of fatality by Cox regression.

\begin{tabular}{|c|c|c|c|c|c|}
\hline Independent predictors & B & SE & Wald & HR $(95 \% C I)$ & P-Value \\
\hline \multicolumn{6}{|l|}{ Serum IL-1 } \\
\hline $\begin{array}{l}\geq 45 \mathrm{pg} / \mathrm{ml} \\
\leq 45 \mathrm{pg} / \mathrm{ml}\end{array}$ & 0.856 & 0.350 & 5.973 & $\begin{array}{l}2.4(1.2-4.7) \\
1 \text { reference }\end{array}$ & 0.015 \\
\hline Serum TBARS & & & & & \\
\hline $\begin{array}{l}\geq 1.4 \mu \mathrm{mol} / \mathrm{L} \\
\leq 1.4 \mu \mathrm{mol} / \mathrm{L}\end{array}$ & 0.692 & 0.338 & 4.186 & $\begin{array}{l}2(1.03-3.9) \\
1 \text { reference }\end{array}$ & 0.041 \\
\hline Serum IL-10 & & & & & \\
\hline
\end{tabular}




\begin{tabular}{llllll}
\hline Independent predictors & B & SE & Wald & HR (95\%CI) & P-Value \\
\hline $\begin{array}{l}\text { GCS admission } \\
\leq 7\end{array}$ & & & & & \\
$>7$ & 1.682 & 0.338 & 24.702 & $\begin{array}{l}\text { 1 (2.7710.4) } \\
1 \text { reference }\end{array}$ & $<0.0001$ \\
\hline
\end{tabular}

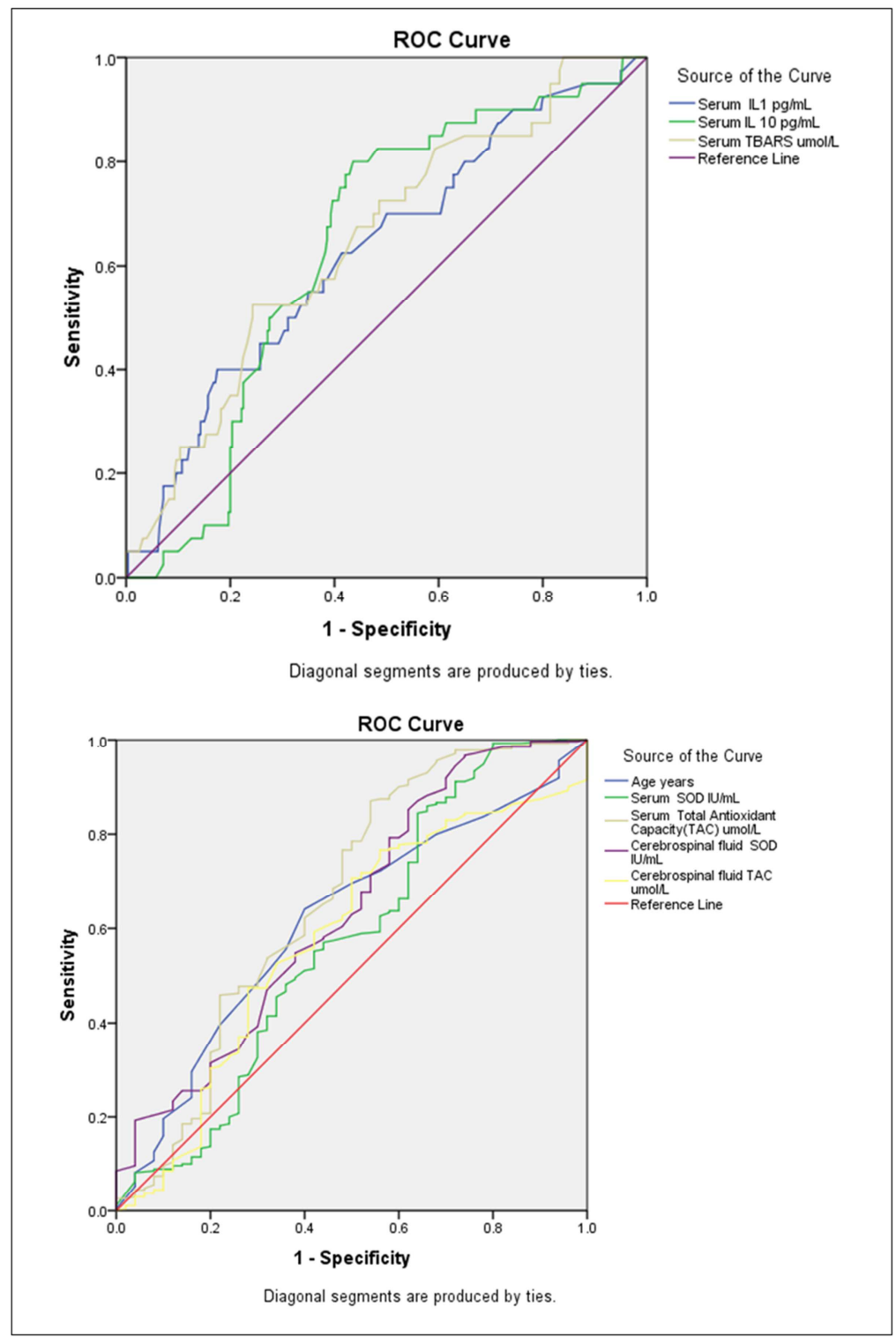

Figure 1. Significant univariate predictors of fatality using ROC curves.

\subsection{Kaplan Meier Analysis for Prediction of Fatality in TBI}

The cumulative probability of fatality by time (survival free of event) was characterized by stratification of independent predictors (serum IL-10, serum IL-1 $\beta$, serum TBARS, admission GCS according to Log Rank test (Mantel-Cox) of Kaplan-Meier curves.

\subsubsection{Kaplan Meier Analysis of GCS at 2 Weeks (Day-14)}

Stratified by two groups of GCS $\leq 8$ at 2 weeks with overall comparisons of durations of Log Rank (Mantel-Cox); $\mathrm{P}<0.0001$ depicts survival functions using Kaplan Meier curve.

Patients with GCS of $>8$ at two weeks had a high probability of survival $(96 \% ; \mathrm{P}<0.0001)$ compared to those whose GCS was $<8$. This indicates that a GCS of $<8$ at weeks is a negative predictor of survival and is highly predictive of fatal outcome.

\subsubsection{Kaplan Meier Analysis of GCS at 3 Months as an Indicator of Survival}

Stratified by two groups of GCS $<$ or $>7$ at admission with overall comparisons of durations of Log Rank (Mantel-Cox); $\mathrm{P}<0.0001$ depicts survival functions using Kaplan Meier curves (Figure 2). 


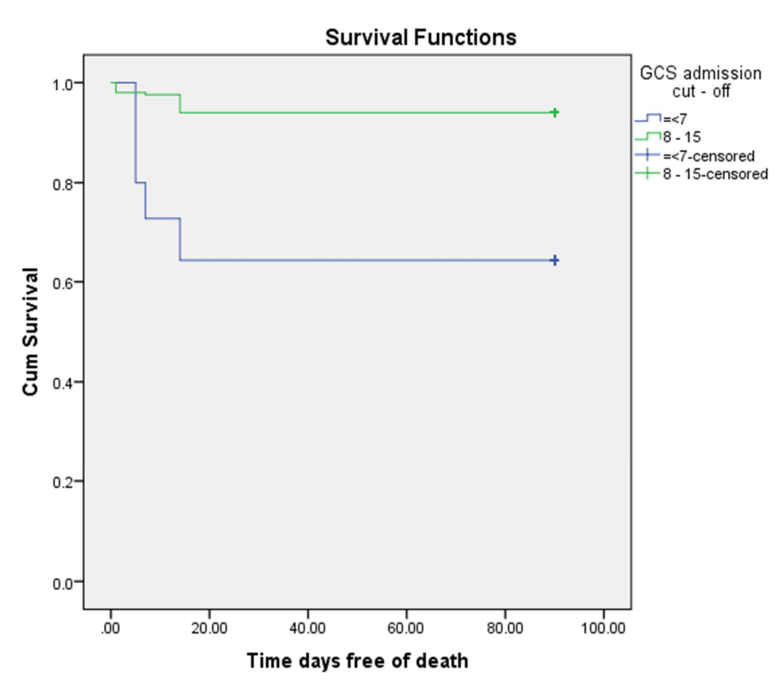

Figure 2. Kaplan Meier curves for GCS prognostication at 3 months

The probability of survival based on GCS $>7$ was significantly higher $(94 \%)$ than the probability of survival in patients with GCS $<7$. The cumulative proportion of patients with GCS $\leq 7$ likely to survive by day 90 was low $(64.3 \%$; mean duration of survival $=60.6 \pm 4.7$ days). This is significantly lower than the cumulative proportion of patients with GCS $>7$ surviving (94\%; mean duration of survival $=85.2 \pm 1.2$ days; $p$ value $=<0.0001$. .

\subsubsection{Kaplan Meier Analysis of Serum Interleukin-10 as an Indicator of Survival}

Stratified by two groups of serum interleukin-10 cut-off of $\geq 60 \mathrm{pg} / \mathrm{mL}$ or $\leq 60 \mathrm{pg} / \mathrm{mL}$ with overall comparison of durations of log Rank (Mantel-Cox); p <0.0001 depicts survival functions using Kaplan-Meier curves for cumulative survival (Figure 3).

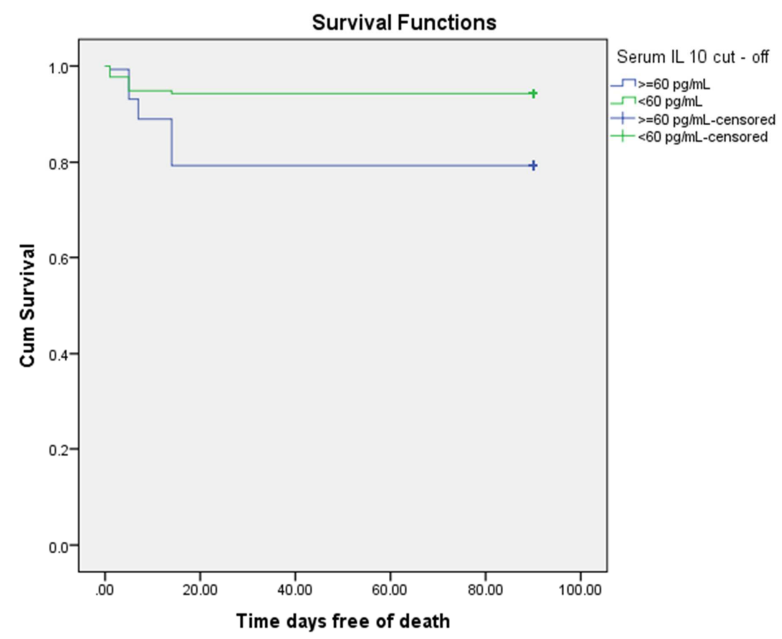

Figure 3. Shows Kaplan Meier curves for serum IL-10.

The estimation of the cumulative proportion of patients surviving by day 90 with serum IL-10<60 pg/ml, was $94.3 \%$ with a mean duration of survival being $85.1 \pm 1.5$ days, this was significantly higher than the cumulative proportion of patients surviving with IL-10 $>60 \mathrm{pg} / \mathrm{ml}$ and with a mean duration of survival $=73.3 \pm 2.7$ days ( $\mathrm{P}$-value $<0.0001$ ).

\subsubsection{Kaplan Meier Analysis of Serum Interleukin-1及 as an Indicator of Survival}

Stratified by two groups of sera interleukin- $1 \beta$ cut-off of $\geq 45 \mathrm{pg} / \mathrm{ml}$ or $\leq 45 \mathrm{pg} / \mathrm{ml}$ with overall comparisons of durations using log Rank (Mantel-Cox) P value $<0.0001$ depicts survival functions using Kaplan Meier curves for serum IL-1 $\beta$ cumulative survival (Figure 4 ).

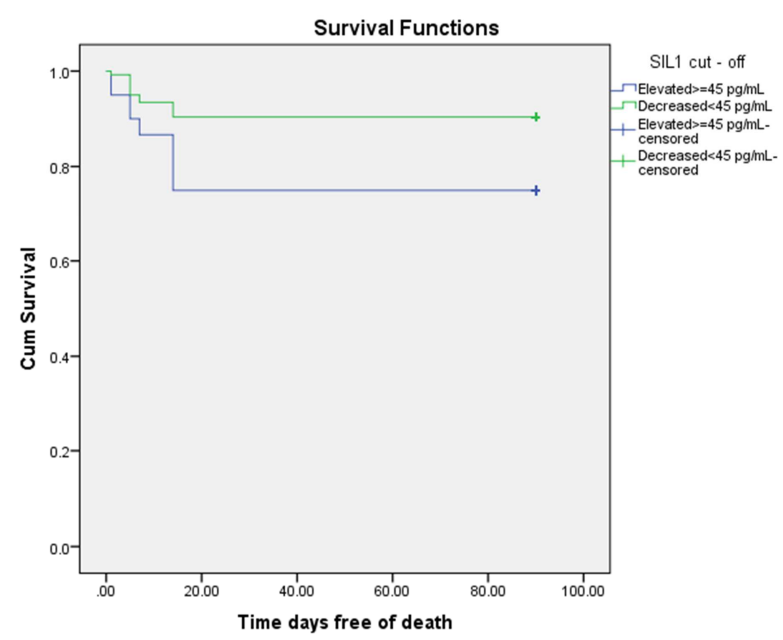

Figure 4. Kaplan Meier curves for serum IL-1 $\beta$.

The estimation of the cumulative proportion of patients with IL-1 $\beta>45 \mathrm{pg} / \mathrm{ml}$ surviving on day 90 was $75 \%$ with a mean duration for survival $=69.7 \pm 4.6$ days, this was significantly lower than when IL- $1 \beta$ levels $<45 \mathrm{pg} / \mathrm{ml}$ were the cumulative proportion of survival was $90.4 \%$ with a mean duration of survival being longer $(82.1 \pm 1.5$ days; $P$ value $<0.001)$.

\subsubsection{Kaplan Meier Analysis of Serum MDA (by TBARS Assay) to Predict Survival and Fatality}

Stratified by two groups of serum TBARS measurements of MDA cut-off of $\geq 1.4 \mu \mathrm{mol} / \mathrm{L}$ or $\leq 1.4 \mu \mathrm{mol} / \mathrm{L}$ with overall comparison of durations using log Rank (Mantel-Cox) $\mathrm{P}=0.033$ depicts survival functions using Kaplan Meier's curves for cumulative survival (Figure 5). The estimation of the cumulative proportion of patients with MDA (serum TBARS) levels $\geq 1.4 \mu \mathrm{mol} / \mathrm{L}$ surviving by day 90 was $81.3 \%$ with a mean duration of survival being $=74.7 \pm 3.3$ days, this was significantly lower than the survival of $90 \%$ in patients with TBARS level $<1.4 \mu \mathrm{mol} / \mathrm{L}$, with a mean duration of survival of $81.6 \pm 1.6$ days $(\mathrm{P}$ value $=0.033)$.

The biomarkers with the highest risk factors for fatality were; serum IL- $\beta \geq 45 \mathrm{pg} / \mathrm{ml}$, serum MDA $\geq 1.4 \mu \mathrm{mol} / 1$ likely, serum IL- $1 \beta \geq 45 \mathrm{pg} / \mathrm{mL}$.

\section{Discussion}

The management of ICP is important in reducing morbidity or mortality in TBI patients [41, 59]. Various studies have 
revealed that better clinical outcomes may be obtained from treating ICP, the brain trauma foundation guidelines recommend treatment for $\mathrm{ICP}>20 \mathrm{mmHg}[1,64,72,84]$.

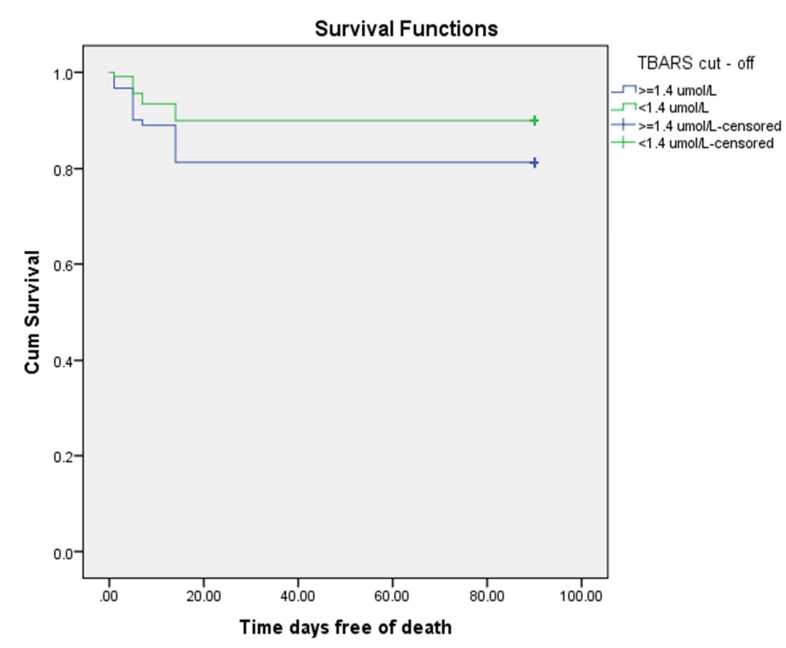

Figure 5. Kaplan Meier curves for serum TBARS.

Potential and Independent Predictors of Fatality in TBI Patients

Prognosis of fatal outcomes from admission to discharge

Univariate analysis using receiver operating curves (ROC)

Though prognostic models based on early clinical data have been used to determine patient outcomes in TBI patients, their use has not been universal due to limitation of external validation. This study attempts to combine and correlate clinical and biochemical data and relate this to clinical outcomes in patients with moderate to severe TBI.

We aimed to determine clinical outcomes not only based on admission characteristics but also on the physiological and biochemical characteristics of biomarkers during the management of these patients.

Out of the 64 patients, $12.5 \%$ died $(n=8)$ and $87.5 \%(n=56)$ survived during the 90-day period of management and follow up. Independent predictors of fatality among the clinical and biological markers were identified using univariate and multivariate analysis.

Using receiver operating curve analysis, a threshold value of serum IL- $1 \beta \geq 45 \mathrm{pg} / \mathrm{mL}$ was found to be predictive of poor outcomes. The ROC curve prognostic performance of serum IL- $1 \beta \geq 45 \mathrm{pg} / \mathrm{mL}$ in predicting a 90 -day fatality was estimated to have a sensitivity of $70 \%$ and specificity of $51 \%$ (AUC $=0.629 ; 95 \% \mathrm{CI}=0.537-0.721 ; \mathrm{p}$ value $=0.008$ ). Thus, in this study, there was increased mortality in patients whose IL-1 $\beta$ levels exceeded the threshold demonstrated. This predictive ability of interleukin- $1 \beta$ is most likely due to its pro-inflammatory effects.

Interleukin-1 $\beta$ is a pro-inflammatory cytokine that enhances neuro-inflammation and aggravates blood brain barrier breakdown. Pro-inflammatory responses may have far reaching effects on patient outcomes in TBI. Uncontrolled IL-1 $\beta$ pro-inflammatory responses in TBI affect the recovery of patients and lead to increased morbidity and mortality among these patients [78]. Various studies show the degree of elevation of IL-1 $\beta$ to be correlated with the severity of traumatic brain injury and can be predictive of poor clinical outcomes [52]. The upregulation of IL-1 $\beta$ expression that occurs after TBI, may worsen hemorrhagic contusions, neuronal tissue injury and lead to exacerbation of brain edema by causing a breakdown of the blood brain barrier [14, 77]. Kaplan Meier estimation of the cumulative proportion of patients with serum IL- $1 \beta>45 \mathrm{pg} / \mathrm{ml}$ surviving by day 90 was $75 \%$ (mean duration for survival $=69.7 \pm 4.6$ days), this is significantly lower $(\mathrm{P}<0.001)$ than the survival duration when the IL- $1 \beta$ levels is $<45 \mathrm{pg} / \mathrm{ml}$, in this case the cumulative proportion of patients surviving was $90.4 \%$ (mean duration of survival $=82.1 \pm 1.5$ days).

This study shows that low levels of IL-1 $\beta(\leq 45 \mathrm{pg} / \mathrm{ml})$ were associated with prolonged survival in our patients. These findings highlight the impact of elevated serum IL-1 $\beta$ levels $(>45 \mathrm{pg} / \mathrm{ml})$, a pro-inflammatory mediator on survival of patients with TBI. Various studies show that the upregulation of interleukin-1 $\beta$, leads to increased proinflammatory activity with resultant exacerbation of neuronal tissue injury [22, 87]. An increased activity of IL-1 $\beta$ after TBI, may also worsen brain edema and hemorrhagic contusion and lead to poor clinical outcomes [14, 77]. A lower concentration of serum IL- $\beta(\leq 45 \mathrm{pg} / \mathrm{ml})$ during management of TBI patients seems to be the evidence of a reduced pro-inflammatory response and aids in clinical recovery of these patients as demonstrated by the prolonged survival in these patients ( $\mathrm{p}$-value $<0.001$ ). These findings are similar to those in other studies that demonstrated an association between elevated cytokines (serum IL-1 $\beta$, IL-10, TNF- $\alpha$ ) with poor outcomes and increased mortality $[69,73]$.

Analysis using receiver operating curves (ROC) to predict 90-day fatality among our TBI patients identified CSF SOD $\leq$ $0.3 \mathrm{IU} / \mathrm{mL}$ as predictive of fatality with a sensitivity of $70 \%$ and specificity of $50 \%(\mathrm{AUC}=0.647 ; 95 \% \mathrm{CI}=0.548-0746$; $\mathrm{P}$ value $=0.003$ ). Thus, patients with a lower cerebrospinal fluid SOD $<0.3 \mathrm{IU} / \mathrm{mL}$ had a high 90 -day mortality compared to patients with high CSF SOD values. This is a clear reflection of the impact of reduced enzymatic anti-oxidant activity and associated increased reactive oxygen species generation on survival of patients with TBI.

The increased generation of reactive oxygen species including superoxide anions during TBI results in neuronal tissue damage, and increased brain edema. To correct this oxidative stress imbalance the host anti-oxidant mechanisms are activated with resultant heightened activity of superoxide dismutase and increased total anti-oxidant levels [8].

Multivariate and univariate analysis revealed a threshold value of serum IL-10 of $60 \mathrm{pg} / \mathrm{ml}$ to be predictive of clinical outcomes. Based on receiver operative curve analysis, levels of serum IL-10 $>60 \mathrm{pg} / \mathrm{ml}$ were predictive of 90-day fatality (Area Under Curve $=0.639 ; 95 \% \mathrm{CI}=0.560-0.719$; $\mathrm{p}$-value < 0.004 ) with a sensitivity of $75 \%$ and a specificity of $68 \%$. It was noted that increased IL-10 levels beyond this threshold value was associated with increased mortality among the TBI patients. The cumulative proportion of patients surviving by day 90 , based on levels of interleukin-10 $<60 \mathrm{pg} / \mathrm{ml}$ was 
$94.3 \%$ (the mean duration of survival $=85.1 \pm 1.5$ days), this is significantly higher $(\mathrm{P}$-value $<0.0001)$ than the proportion of patients surviving with IL-10 $>60 \mathrm{pg} / \mathrm{ml}$ (mean duration of survival $=73.3 \pm 2.7$ days). Though IL-10 has important antiinflammatory effects, levels $>60 \mathrm{pg} / \mathrm{ml}$ may have a counterproductive impact on survival. It is likely that disproportionally elevated levels of interleukin-10 ( $>60$ $\mathrm{pg} / \mathrm{ml}$ ) are associated with loss of the anti-inflammatory response and may exacerbate the inflammatory process leading to further neuronal damage. Similar findings of elevated IL-10 being associated with increased mortality among TBI patients have been demonstrated in various studies [16, 73]. Interleukin-10 an important antiinflammatory marker, is of value in predictive survival in patients with TBI. The cumulative number of patients with interleukin-10 levels $<60 \mathrm{pg} / \mathrm{ml}$ who survived was far greater than in patients who had IL-10 levels $>60 \mathrm{pg} / \mathrm{ml}$ during the period of management $(p<0.0001)$. Though IL-10 is anti-inflammatory in action, levels higher than $60 \mathrm{pg} / \mathrm{ml}$ may be detrimental and may impact negatively on survival. However, there is enough evidence to support the observation that anti-inflammatory effects of Interleukin-10 downregulate and suppress pro-inflammatory cytokine production [38, 63].

The 90 -day mortality prediction using ROC also identified the prognostic significance of serum total anti-oxidant capacity (TAC). Serum TAC levels $\leq 450 \mu \mathrm{mol} / \mathrm{L}$ had sensitivity of $70 \%$ and specificity of $60 \%$ in predicting fatality (AUC $=0.724 ; 95 \%$ CI $0.827-0.907$; $p$ value $<0.0001$ ). Patients with values lower than the threshold were more likely to have poor outcomes and to die by day 90 . These tests were noted to be significant in identifying the possible predictors of poor outcomes and fatality but must be combined with the other clinical parameters including, CT scan findings and intracranial pathology.

This study further identified the Glasgow Coma Score (GCS) of $\leq 7$ as being highly predictive of 90-day fatal outcomes. Indeed, ROC curve analysis identified the predictive value of GCS $\leq 7$ in our TBI patients (AUC $=0.867$ 95\% CI $=0.827-0.907 ; \mathrm{P}$ value $<0.0001$; sensitivity $84 \%$, specificity $=70 \%$ ). In this study, the high AUC and sensitivity in predicting fatal outcomes as noted exceeded that of any other models or markers used. This high prognostic potential of GCS has been demonstrated in other studies that showed GCS as a significant predictor of neurological recovery in TBI patients [33, 61]. The findings in this study serve to demonstrate GCS as an important tool in predicting clinical outcomes in patients with moderate to severe TBI. Various other studies have also shown the importance of the admission GCS or GCS motor score in predicting fatality in TBI patients [33, 67]. Beside the GCS, various studies show pupillary reactivity to be an important clinical predictor of outcomes in TBI patients. Furthermore, Cox regression analysis in this study reveals an admission GCS of $\leq 7$ to be highly predictive of mortality after TBI (HR 5.4 [95\% $\mathrm{CI}=2.77-10.4] \mathrm{P}<0.0001)$.

Other studies identified the motor score in the admission GCS as being the single most important predictor of mortality [46].
Thus, clinical parameters used in outcome prediction for TBI patients have included age, pupillary reactivity, GCS, motor component in the GCS, body temperature, significant noncranial injuries and blood glucose [44, 71].

Kaplan Meier estimation of the cumulative proportion of patients with an admission GCS $\leq 7$ surviving on day 90 , was estimated to be $64.3 \%$ with a mean duration to survival of $60.6 \pm 4.7$ days, which is significantly lower ( $p$ value $<0.0001$ ) than the 90-day survival of $94 \%$ (mean duration of survival $=85.2 \pm 1.2$ ) in patients with an admission GCS $>7$. This study reveals that the admission Glasgow Coma Score assessment not only gives information on the state of consciousness but is highly predictive of clinical outcomes. These findings are similar to those in other studies which identified GCS as an important predictor of clinical outcomes in patients with TBI $[46,62]$. Indeed as in the corticosteroid randomized control study (CRASH) [71] the GCS coma score was highly predictive of fatality.

This study reveals that the GCS can be used in prediction of fatality and in estimation of survival probability in TBI patients. The multiple studies on clinical and biological markers to determine prognostic and predictive potential have revealed important findings and support early neurosurgical intervention to minimize the oxidative stress imbalance and limit the pro-inflammatory response in TBI patients. Based on Kaplan Meier curves, this study shows that admission GCS $>7$ is highly significant in predicting the survival of patients with a probability of survival at 3 months (90 days) being 94\% (p-value $<0.0001$ ) in TBI patients. Similar findings as observed by Teasdale and Jennett revealed the GCS to be important not only in assessment of patients with traumatic brain injury but also in predicting clinical outcomes [74]. These findings, mirror those that revealed the admission GCS as an important prognostic marker for clinical recovery after TBI $[33,61]$.

The ROC curve prognostic performance in predicting fatality using thiobarbituric acid reactive substances (TBARS) assay to assess malondialdehyde a product of lipid peroxidation also revealed a sensitivity of $73 \%$ and specificity of $51 \%$ (Area Under Curve 0.649 ; 95\% CI: 0.561 $0.736 \mathrm{P}$-value $=0.002$ ), when the value of serum MDA was $\geq$ $1.4 \mu \mathrm{mol} / \mathrm{L}$. Increased oxidative stress imbalance in TBI leads to increased lipid peroxidation with resultant generation of malondialdehyde and other neurotoxic aldehydes in these patients $[11,27,28]$. Termination lipid peroxidation requires the presence of an efficient endogenous antioxidant system $[10,25,51,53,83]$.

Our study shows that exaggerated elevation of the malondialdehyde $\geq 1.4 \mu \mathrm{mol} / \mathrm{L}$ is prognostic of fatality in these patients. Similar findings have been revealed by studies that demonstrated high levels of malondialdehyde (MDA) to be predictive of fatal outcomes after TBI $[42,43,60]$. In patients with severe TBI, reactive aldehydes including malondialdehyde become elevated, these not only cause neuronal tissue injury but also cause; blood brain barrier disruption, increase cerebrovascular permeability and interruption of glucose transport across cerebral biological 
membranes and can contribute to poor clinical outcomes in these patients [17-19]. This study reveals that elevated malondialdehyde (MDA) levels $\geq 1.4 \mu \mathrm{mol} / \mathrm{L}$ may determine clinical outcomes following TBI. Serum MDA $\geq 1.4 \mu \mathrm{mol} / \mathrm{L}$ predicted a 90-day mortality with increased risk of fatal outcomes as revealed by Cox regression analysis (HR: 2 [95\% $\mathrm{CI}=1.03-3.9], \mathrm{P}=0.041$ ). These findings are similar to those in a recent study which found a significant association between elevated MDA levels and early 30-day mortality. Thus, high serum malondialdehyde levels were noted to be predictive of mortality in TBI patients [43].

Elevated serum MDA levels are highly indicative of oxidative stress imbalance which impacts significantly on survival and mortality in patients with moderate to severe TBI. The management of TBI patients should not only be directed at the removal of the offending lesion but also at correcting the metabolic state, oxidative stress imbalance and inflammatory response. Kaplan Meier estimation of the cumulative proportion of patients with serum MDA levels $>1.4 \mu \mathrm{mol}$ surviving by day 90 was $81.3 \%$ (mean duration of survival $=74.7 \pm 3.3$ days) this is significantly lower than when the serum MDA levels were $<1.4 \mu \mathrm{mol} / 1$ where $90 \%$ of the patients survived (mean duration of survival $=81.6 \pm 1.6$ days $p$ value $=0.033$ ).

Efficient management of patients with moderate to severe TBI results in the resolution of oxidative stress imbalance and can reduce lipid peroxidation. This can lead to a reduction in the concentration of serum MDA levels and may prolong survival and reduce mortality in these patients as shown in the study. This study shows that serum biomarker values elevated above the thresholds (IL- $1 \beta \geq 45 \mathrm{pg} / \mathrm{ml}$, MDA Cut-off $\geq 1.4 \mu \mathrm{mol} / \mathrm{l}$ ) are risk factors for fatality among patients with moderate to severe TBI. In this study, low levels of serum MDA are associated with prolonged survival among TBI patients. Various studies show that increased lipid peroxidation results in high MDA levels in patients with severe TBI [11, 27, 28]. Our study highlights this fact and demonstrates that the higher the MDA levels, the greater the oxidative stress imbalance and the more likely the outcome will be fatal. Thus, as in previously documented studies increased lipid peroxidation manifested by high MDA levels has been seen to be associated with increased mortality and poor neurological outcomes in TBI patients [42, 43].

Indeed, several studies have been done to find an optimum or ideal biomarker in predicting clinical outcomes in TBI patients. This is revealed by the number of studies done to evaluate the role of several of these biomarkers including S100B, glial fibrillary acidic protein, Neuron specific enolase, myelin basic protein among others. The impact of many of these markers evaluated within a few hours after injury has not been significant for universal application [9]. In identifying clinical, physiological and biochemical profiles among TBI patients our study not only defines the trends of the biomarkers during management but also correlates these trends with the clinical outcomes.

This study has helped identify the role of biomarkers in predicting fatality and clinical recovery. The biomarkers were evaluated from the day of admission and surgical intervention to day 14. Studies done on biomarkers in diagnosis and prognosis of TBI have revealed varied results and in many cases, have shown low specificities and sensitivities hence their limited role. Some of these studies on TBI show that early biomarkers including the calcium binding protein $(\mathrm{S} 100 \mathrm{~B})$, and glial fibrillary acidic protein may be of use in guiding the assessment, management and predicting clinical outcomes in TBI patients [58, 80].

The biomarkers identified and their cut-off values included serum IL- $1 \beta \geq 45 \mathrm{pg} / \mathrm{mL}$ serum $\mathrm{MDA} \geq 1.4 \mu \mathrm{mol} / \mathrm{L}$, serum IL-10 $\geq 60 \mathrm{pg} / \mathrm{mL}$ and GCS at admission $\leq 7$. These were identified as the most important or significant Risk factors for fatal outcomes. Other studies have shown elevated levels of inflammatory markers particularly serum IL- $1 \beta$ and IL-10 to been associated with increased mortality in patients with TBI [20, 39, 73].

Regarding biomarkers, there are several other studies done to define the correlation between biomarkers and outcomes in TBI. The biomarkers studied included, neuron specific enolase, glial fibrillary acidic proteins, S100B protein, myelin basic protein, cleaved tau protein, spectrin break down products, ubiquitin C-terminal hydrolase-1 (UCH-L1), besides apolipoprotein E, angiotensin-1 converting enzyme, D2 dopamine receptor subtype, P53 gene, Catechol-Omethyltransferase, neuroglobin as well interleukin-1 [23, 32, $35,54,86]$. These biomarkers though useful did not exhibit consistent specificity and sensitivity for universal use. Thus, none of the biomarkers had a clear and concise impact for universal application in prognostication in traumatic brain injury.

In this study, Cox regression analysis revealed an increased mortality in TBI patients when the following threshold values of inflammatory biomarkers were exceeded; serum IL-1 $3 \geq 45 \mathrm{pg} / \mathrm{mL}$ (HR 2.4 (95\% CI=1.2-4.7), Pvalue $=0.015)$, serum IL-10 $\geq 60 \mathrm{pg} / \mathrm{mL} \quad(\mathrm{HR} \quad 3.7 \quad[95 \%$ $\mathrm{CI}=1.76-7.7], \mathrm{P}$ value $<0.001)$. In Cox regression analysis, the multivariate hazard ratio for fatal outcomes was multiplied by $x 5, x 4, x 2$, x2, for; admission GCS $<7$, serum IL $10 \geq 60$ $\mathrm{pg} / \mathrm{mL}$, serum $\mathrm{MDA} \geq 1.4 \mu \mathrm{mol} / \mathrm{L}$, serum IL- $1 \beta \geq 45 \mathrm{pg} / \mathrm{mL}$ respectively.

\section{Efficiency of Neurosurgical Intervention}

At admission $100 \%$ of the patients presented with a low level of consciousness and a GCS $\leq 12$. At the end of 2 weeks almost $10 \%$ of these patients had died. Our results show that after 2 weeks, the GOS showed that $66 \%$ of patients had good functional state, $11 \%$ moderate disability, $14 \%$ severe disability and $9 \%$ persistent vegetative state. At 90 days $66 \%$ patients presented with good cerebral functional status but less than $15 \%$ of the living patients presented with severe disability and persistent vegetative state. This study shows that aggressive neurosurgical intervention with multimodality monitoring and management of ICP, $\mathrm{PBO} 2$ resulting in 
improvement in clinical condition of these patients.

\section{Conclusions}

Glasgow Coma Scale particularly the admission GCS is an important clinical marker not only in assessing patients but also in predicting clinical outcomes in TBI patients.

In traumatic brain injury, high levels of malondialdehyde (TBARS) are a manifestation of increased oxidant activity as well as oxidative stress imbalance and are prognostic of fatal outcomes in these patients.

Persistent elevation of interleukin-1 $\beta$ (IL-1 $\beta$ ) levels in traumatic brain injury patients is associated with increased mortality among these patients.

Exaggerated elevation of serum IL-10 levels is not necessarily protective and may be correlated with increased mortality among TBI patients.

This study reveals that standard neurosurgical management of patients with moderate to severe traumatic brain injury involves modulation of inflammatory and oxidative stress changes which may impact on clinical outcomes.

\section{Declaration}

The Walter Sisulu University research office provided the funding to purchase laboratory kits for this study. This funding was granted to Dr Kadhaya David Muballe during his $\mathrm{PhD}$ work. This study was part of the PhD done by KD Muballe at the Walter Sisulu University.

There is no perceived conflict of interest in this study.

No part of this study has been submitted for publication or been presented at any meeting

\section{Acknowledgements}

I would like to extend my deepest gratitude to the neurosurgical team of registrars (Dr. L Nqoloba and Dr. Mabovula) and SHOs Dr. Godana who assisted with sample collection.

To the Nursing team in the operating room, the intensive care unit and the trauma high care units at the Nelson Mandela academic hospital who assisted in taking care of these patients.

\section{References}

[1] Alali AS, Fowler RA, Mainprize TG, Scales DC, Kiss A, de Mestral C, et al: Intracranial pressure monitoring in severe traumatic brain injury: results from the American College of Surgeons Trauma Quality Improvement Program. J Neurotrauma 30: 1737-1746, 2013.

[2] Allan SM, Rothwell NJ: Cytokines and acute neurodegeneration. Nat Rev Neurosci 2: 734-744, 2001.

[3] Andelic N, Anke A, Skandsen T, Sigurdardottir S, Sandhaug $\mathrm{M}$, Ader $\mathrm{T}$, et al: Incidence of hospital-admitted severe traumatic brain injury and in-hospital fatality in Norway: a national cohort study. Neuroepidemiology 38: 259-267, 2012.
[4] Andelic N, Hammergren N, Bautz-Holter E, Sveen U, Brunborg C, Roe C: Functional outcome and health-related quality of life 10 years after moderate-to-severe traumatic brain injury. Acta Neurol Scand 120: 16-23, 2009.

[5] Andriessen TM, Horn J, Franschman G, van der Naalt J, Haitsma I, Jacobs B, et al: Epidemiology, severity classification, and outcome of moderate and severe traumatic brain injury: a prospective multicenter study. J Neurotrauma 28: 2019-2031, 2011

[6] Baskaya MK, Rao AM, Dogan A, Donaldson D, Dempsey RJ: The biphasic opening of the blood-brain barrier in the cortex and hippocampus after traumatic brain injury in rats. Neurosci Lett 226: 33-36, 1997.

[7] Bast A, Haenen GR, Doelman CJ: Oxidants and antioxidants: state of the art. Am J Med 91: 2S-13S, 1991.

[8] Batinic-Haberle I, Rajic Z, Tovmasyan A, Reboucas JS, Ye X, Leong KW, et al: Diverse functions of cationic Mn (III) Nsubstituted pyridylporphyrins, recognized as SOD mimics. Free Radic Biol Med 51: 1035-1053, 2011.

[9] Berger RP, Adelson PD, Pierce MC, Dulani T, Cassidy LD, Kochanek PM: Serum neuron-specific enolase, S100B, and myelin basic protein concentrations after inflicted and noninflicted traumatic brain injury in children. J Neurosurg 103: 61-68, 2005 .

[10] Chan AC: Partners in defense, vitamin E and vitamin C. Can J Physiol Pharmacol 71: 725-731, 1993.

[11] Cristofori L, Tavazzi B, Gambin R, Vagnozzi R, Vivenza C, Amorini AM, et al: Early onset of lipid peroxidation after human traumatic brain injury: a fatal limitation for the free radical scavenger pharmacological therapy? J Investig Med 49: 450-458, 2001.

[12] Dardiotis E, Fountas KN, Dardioti M, Xiromerisiou G, Kapsalaki E, Tasiou A, et al: Genetic association studies in patients with traumatic brain injury. Neurosurg Focus 28: E9, 2010 .

[13] Demetriades D, Kuncir E, Murray J, Velmahos GC, Rhee P, Chan L: Mortality prediction of head Abbreviated Injury Score and Glasgow Coma Scale: analysis of 7, 764 head injuries. J Am Coll Surg 199: 216-222, 2004.

[14] Denes A, Pradillo JM, Drake C, Sharp A, Warn P, Murray KN, et al: Streptococcus pneumoniae worsens cerebral ischemia via interleukin 1 and platelet glycoprotein Ibalpha. Ann Neurol 75: 670-683, 2014.

[15] DeWitt DS, Prough DS: Traumatic cerebral vascular injury: the effects of concussive brain injury on the cerebral vasculature. J Neurotrauma 20: 795-825, 2003.

[16] Di Battista AP, Rhind SG, Hutchison MG, Hassan S, Shiu MY, Inaba K, et al: Inflammatory cytokine and chemokine profiles are associated with patient outcome and the hyperadrenergic state following acute brain injury. J Neuroinflammation 13: 40, 2016.

[17] Esterbauer H, Cheeseman KH: Determination of aldehydic lipid peroxidation products: malonaldehyde and 4hydroxynonenal. Methods Enzymol 186: 407-421, 1990.

[18] Esterbauer H, Schaur RJ, Zollner H: Chemistry and biochemistry of 4-hydroxynonenal, malonaldehyde and related aldehydes. Free Radic Biol Med 11: 81-128, 1991. 
[19] Esterbauer H, Zollner H: Methods for determination of aldehydic lipid peroxidation products. Free Radic Biol Med 7: 197-203, 1989.

[20] Ferreira LC, Regner A, Miotto KD, Moura S, Ikuta N, Vargas $\mathrm{AE}$, et al: Increased levels of interleukin-6, -8 and -10 are associated with fatal outcome following severe traumatic brain injury. Brain Inj 28: 1311-1316, 2014.

[21] Foreman BP, Caesar RR, Parks J, Madden C, Gentilello LM, Shafi S, et al: Usefulness of the abbreviated injury score and the injury severity score in comparison to the Glasgow Coma Scale in predicting outcome after traumatic brain injury. J Trauma 62: 946-950, 2007.

[22] Fouda AY, Kozak A, Alhusban A, Switzer JA, Fagan SC: Antiinflammatory IL-10 is upregulated in both hemispheres after experimental ischemic stroke: Hypertension blunts the response. Exp Transl Stroke Med 5: 12, 2013.

[23] Gallek MJ, Ritter L: Central nervous system genomics. Annu Rev Nurs Res 29: 205-226, 2011.

[24] Goodman JC, Robertson CS, Grossman RG, Narayan RK: Elevation of tumor necrosis factor in head injury. $\mathrm{J}$ Neuroimmunol 30: 213-217, 1990.

[25] Halliwell B: Oxygen radicals as key mediators in neurological disease: fact or fiction? Ann Neurol 32 Suppl: S10-15, 1992.

[26] Helmy A, Carpenter KL, Menon DK, Pickard JD, Hutchinson PJ: The cytokine response to human traumatic brain injury: temporal profiles and evidence for cerebral parenchymal production. J Cereb Blood Flow Metab 31: 658-670, 2011.

[27] Hohl A, Gullo Jda S, Silva CC, Bertotti MM, Felisberto F, Nunes JC, et al: Plasma levels of oxidative stress biomarkers and hospital mortality in severe head injury: a multivariate analysis. J Crit Care 27: 523 e511-529, 2012.

[28] Hu S, Zheng L, Chen B, Xie J, Yang C: [The role of the leukocytes in pathogenesis of secondary brain injury]. Hunan Yi Ke Da Xue Xue Bao 24: 56-58, 1999.

[29] Hudome S, Palmer C, Roberts RL, Mauger D, Housman C, Towfighi J: The role of neutrophils in the production of hypoxic-ischemic brain injury in the neonatal rat. Pediatr Res 41: 607-616, 1997.

[30] Hukkelhoven CW, Steyerberg EW, Habbema JD, Farace E, Marmarou A, Murray GD, et al: Predicting outcome after traumatic brain injury: development and validation of a prognostic score based on admission characteristics. J Neurotrauma 22: 1025-1039, 2005.

[31] Ikeda Y, Anderson JH, Long DM: Oxygen free radicals in the genesis of traumatic and peritumoral brain edema. Neurosurgery 24: 679-685, 1989.

[32] Ji X, Tian Y, Xie K, Liu W, Qu Y, Fei Z: Protective effects of hydrogen-rich saline in a rat model of traumatic brain injury via reducing oxidative stress. J Surg Res 178: e9-16, 2012.

[33] Jiang JY, Gao GY, Li WP, Yu MK, Zhu C: Early indicators of prognosis in 846 cases of severe traumatic brain injury. J Neurotrauma 19: 869-874, 2002.

[34] Kelly DF, Kordestani RK, Martin NA, Nguyen T, Hovda DA, Bergsneider $M$, et al: Hyperemia following traumatic brain injury: relationship to intracranial hypertension and outcome. J Neurosurg 85: 762-771, 1996.
[35] Kobeissy FH, Ottens AK, Zhang Z, Liu MC, Denslow ND, Dave JR, et al: Novel differential neuroproteomics analysis of traumatic brain injury in rats. Mol Cell Proteomics 5: 18871898, 2006.

[36] Kontos HA, Wei EP, Povlishock JT, Christman CW: Oxygen radicals mediate the cerebral arteriolar dilation from arachidonate and bradykinin in cats. Circ Res 55: 295-303, 1984.

[37] Kretzschmar M, Pfeiffer L, Schmidt C, Schirrmeister W: Plasma levels of glutathione, alpha-tocopherol and lipid peroxides in polytraumatized patients; evidence for a stimulating effect of TNF alpha on glutathione synthesis. Exp Toxicol Pathol 50: 477-483, 1998.

[38] Kubo M, Motomura Y: Transcriptional regulation of the antiinflammatory cytokine IL-10 in acquired immune cells. Front Immunol 3: 275, 2012.

[39] Kumar RG, Boles JA, Wagner AK: Chronic Inflammation After Severe Traumatic Brain Injury: Characterization and Associations With Outcome at 6 and 12 Months Postinjury. J Head Trauma Rehabil 30: 369-381, 2015.

[40] LaPar DJ, Rosenberger LH, Walters DM, Hedrick TL, Swenson BR, Young JS, et al: Severe traumatic head injury affects systemic cytokine expression. J Am Coll Surg 214: 478-486; discussion 486-478, 2012.

[41] Latronico N, Beindorf AE, Rasulo FA, Febbrari P, Stefini R, Cornali $\mathrm{C}$, et al: Limits of intermittent jugular bulb oxygen saturation monitoring in the management of severe head trauma patients. Neurosurgery 46: 1131-1138; discussion 1138-1139, 2000.

[42] Lorente L: New Prognostic Biomarkers in Patients With Traumatic Brain Injury. Arch Trauma Res 4: e30165, 2015.

[43] Lorente L, Martin MM, Abreu-Gonzalez P, Ramos L, Argueso $\mathrm{M}$, Caceres JJ, et al: Association between serum malondialdehyde levels and mortality in patients with severe brain trauma injury. J Neurotrauma 32: 1-6, 2015.

[44] Maas AI, Hukkelhoven CW, Marshall LF, Steyerberg EW: Prediction of outcome in traumatic brain injury with computed tomographic characteristics: a comparison between the computed tomographic classification and combinations of computed tomographic predictors. Neurosurgery 57: 11731182; discussion 1173-1182, 2005.

[45] Mace BE, Wang H, Lynch JR, Moss J, Sullivan P, Colton H, et al: Apolipoprotein E modifies the CNS response to injury via a histamine-mediated pathway. Neurol Res 29: 243-250, 2007.

[46] Marmarou A, Lu J, Butcher I, McHugh GS, Murray GD, Steyerberg EW, et al: Prognostic value of the Glasgow Coma Scale and pupil reactivity in traumatic brain injury assessed pre-hospital and on enrollment: an IMPACT analysis. J Neurotrauma 24: 270-280, 2007.

[47] Marmarou A, Signoretti S, Fatouros PP, Portella G, Aygok GA, Bullock MR: Predominance of cellular edema in traumatic brain swelling in patients with severe head injuries. J Neurosurg 104: 720-730, 2006.

[48] Marshall LF, Marshall SB, Klauber MR, Van Berkum Clark M, Eisenberg H, Jane JA, et al: The diagnosis of head injury requires a classification based on computed axial tomography. J Neurotrauma 9 Suppl 1: S287-292, 1992. 
[49] Masson F, Thicoipe M, Aye P, Mokni T, Senjean P, Schmitt $\mathrm{V}$, et al: Epidemiology of severe brain injuries: a prospective population-based study. J Trauma 51: 481-489, 2001.

[50] Matzinger P: The danger model: a renewed sense of self. Science 296: 301-305, 2002.

[51] May JM, Qu ZC, Whitesell RR, Cobb CE: Ascorbate recycling in human erythrocytes: role of GSH in reducing dehydroascorbate. Free Radic Biol Med 20: 543-551, 1996.

[52] McColl BW, Allan SM, Rothwell NJ: Systemic infection, inflammation and acute ischemic stroke. Neuroscience 158: 1049-1061, 2009

[53] Mendiratta S, Qu ZC, May JM: Erythrocyte ascorbate recycling: antioxidant effects in blood. Free Radic Biol Med 24: 789-797, 1998.

[54] Mondello S, Robicsek SA, Gabrielli A, Brophy GM, Papa L, Tepas J, et al: alphaII-spectrin breakdown products (SBDPs): diagnosis and outcome in severe traumatic brain injury patients. J Neurotrauma 27: 1203-1213, 2010.

[55] Munoz C, Carlet J, Fitting C, Misset B, Bleriot JP, Cavaillon JM: Dysregulation of in vitro cytokine production by monocytes during sepsis. J Clin Invest 88: 1747-1754, 1991.

[56] Murray LS, Teasdale GM, Murray GD, Jennett B, Miller JD, Pickard JD, et al: Does prediction of outcome alter patient management? Lancet 341: 1487-1491, 1993.

[57] Nathan C: Points of control in inflammation. Nature 420: 846$852,2002$.

[58] Okonkwo DO, Yue JK, Puccio AM, Panczykowski DM, Inoue $\mathrm{T}$, McMahon $\mathrm{PJ}$, et al: GFAP-BDP as an acute diagnostic marker in traumatic brain injury: results from the prospective transforming research and clinical knowledge in traumatic brain injury study. J Neurotrauma 30: 1490-1497, 2013.

[59] Palmer S, Bader MK, Qureshi A, Palmer J, Shaver T, Borzatta $\mathrm{M}$, et al: The impact on outcomes in a community hospital setting of using the AANS traumatic brain injury guidelines. Americans Associations for Neurologic Surgeons. J Trauma 50: 657-664, 2001

[60] Paolin A, Nardin L, Gaetani P, Rodriguez YBR, Pansarasa O, Marzatico F: Oxidative damage after severe head injury and its relationship to neurological outcome. Neurosurgery 51: 949-954; discussion 954-945, 2002.

[61] Park JE, Kim SH, Yoon SH, Cho KG, Kim SH: Risk Factors Predicting Unfavorable Neurological Outcome during the Early Period after Traumatic Brain Injury. J Korean Neurosurg Soc 45: 90-95, 2009.

[62] Perel P, Edwards P, Wentz R, Roberts I: Systematic review of prognostic models in traumatic brain injury. BMC Med Inform Decis Mak 6: 38, 2006.

[63] Pestka S, Krause CD, Sarkar D, Walter MR, Shi Y, Fisher PB: Interleukin-10 and related cytokines and receptors. Annu Rev Immunol 22: 929-979, 2004.

[64] Prabhakar H, Sandhu K, Bhagat H, Durga P, Chawla R: Current concepts of optimal cerebral perfusion pressure in traumatic brain injury. J Anaesthesiol Clin Pharmacol 30: 318327, 2014.

[65] Riva-Depaty I, Fardeau C, Mariani J, Bouchaud C, Delhaye-
Bouchaud N: Contribution of peripheral macrophages and microglia to the cellular reaction after mechanical or neurotoxin-induced lesions of the rat brain. Exp Neurol 128: 77-87, 1994.

[66] Rosenberg AL: Recent innovations in intensive care unit riskprediction models. Curr Opin Crit Care 8: 321-330, 2002.

[67] Ross SE, Leipold C, Terregino C, O'Malley KF: Efficacy of the motor component of the Glasgow Coma Scale in trauma triage. J Trauma 45: 42-44, 1998.

[68] Schlag G, Redl H: Mediators of injury and inflammation. World J Surg 20: 406-410, 1996.

[69] Schneider Soares FM, Menezes de Souza N, Liborio Schwarzbold M, Paim Diaz A, Costa Nunes J, Hohl A, et al: Interleukin-10 is an independent biomarker of severe traumatic brain injury prognosis. Neuroimmunomodulation 19 : 377-385, 2012.

[70] Shlosberg D, Benifla M, Kaufer D, Friedman A: Blood-brain barrier breakdown as a therapeutic target in traumatic brain injury. Nat Rev Neurol 6: 393-403, 2010.

[71] Steyerberg EW, Mushkudiani N, Perel P, Butcher I, Lu J, McHugh GS, et al: Predicting outcome after traumatic brain injury: development and international validation of prognostic scores based on admission characteristics. PLoS Med 5: e165; discussion e165, 2008.

[72] Talving P, Karamanos E, Teixeira PG, Skiada D, Lam L, Belzberg $\mathrm{H}$, et al: Intracranial pressure monitoring in severe head injury: compliance with Brain Trauma Foundation guidelines and effect on outcomes: a prospective study. J Neurosurg 119: 1248-1254, 2013.

[73] Tasci A, Okay O, Gezici AR, Ergun R, Ergungor F: Prognostic value of interleukin-1 beta levels after acute brain injury. Neurol Res 25: 871-874, 2003.

[74] Teasdale G, Jennett B: Assessment of coma and impaired consciousness. A practical scale. Lancet 2: 81-84, 1974.

[75] Thorburne SK, Juurlink BH: Low glutathione and high iron govern the susceptibility of oligodendroglial precursors to oxidative stress. J Neurochem 67: 1014-1022, 1996.

[76] Todo H, Ohta S, Wang J, Ichikawa H, Ohue S, Kumon Y, et al Impairment in biochemical level of arterial dilative capability of a cyclic nucleotides-dependent pathway by induced vasospasm in the canine basilar artery. J Cereb Blood Flow Metab 18: 808-817, 1998.

[77] Utagawa A, Truettner JS, Dietrich WD, Bramlett HM: Systemic inflammation exacerbates behavioral and histopathological consequences of isolated traumatic brain injury in rats. Exp Neurol 211: 283-291, 2008.

[78] VanGilder RL, Davidov DM, Stinehart KR, Huber JD, Turner $\mathrm{RC}$, Wilson KS, et al: C-reactive protein and long-term ischemic stroke prognosis. J Clin Neurosci 21: 547-553, 2014.

[79] Vincent JL, Ferreira F, Moreno R: Scoring systems for assessing organ dysfunction and survival. Crit Care Clin 16: $353-366,2000$.

[80] Vos PE, Jacobs B, Andriessen TM, Lamers KJ, Borm GF, Beems T, et al: GFAP and S100B are biomarkers of traumatic brain injury: an observational cohort study. Neurology 75: 1786-1793, 2010. 
[81] Werner C, Engelhard K: Pathophysiology of traumatic brain injury. Br J Anaesth 99: 4-9, 2007.

[82] Williams TI, Lovell MA, Lynn BC: Analysis of derivatized biogenic aldehydes by LC tandem mass spectrometry. Anal Chem 77: 3383-3389, 2005.

[83] Winkler BS, Orselli SM, Rex TS: The redox couple between glutathione and ascorbic acid: a chemical and physiological perspective. Free Radic Biol Med 17: 333-349, 1994.

[84] Yuan Q, Wu X, Sun Y, Yu J, Li Z, Du Z, et al: Impact of intracranial pressure monitoring on mortality in patients with traumatic brain injury: a systematic review and meta-analysis. J Neurosurg 122: 574-587, 2015.

[85] Zhang J, Rivest S: Anti-inflammatory effects of prostaglandin E2 in the central nervous system in response to brain injury and circulating lipopolysaccharide. J Neurochem 76: 855-864, 2001.

[86] Zhang Z, Zoltewicz JS, Mondello S, Newsom KJ, Yang Z, Yang B, et al: Human traumatic brain injury induces autoantibody response against glial fibrillary acidic protein and its breakdown products. PLoS One 9: e92698, 2014.

[87] Zhang ZL, Wu WC, Liu JQ, Yao YB, Pan MD, Yang CB, et al: Screening of differentially expressed genes related to ischemic stroke and functional analysis with DNA microarray. Eur Rev Med Pharmacol Sci 18: 1181-1188, 2014.

[88] Zuccarello M, Boccaletti R, Romano A, Rapoport RM: Endothelin B receptor antagonists attenuate subarachnoid hemorrhage-induced cerebral vasospasm. Stroke 29: 19241929, 1998. 